\title{
Assessing the Role of Motivation on Teacher Performance: Case Study in Indonesia
}

\author{
Irwandy \\ Universitas Negeri Medan, Indonesia \\ E-mail: irwandymanday@gmail.com
}

Received: 20-02- 2013

Accepted: 05-04-2013

Published: 30-04-2014

doi:10.7575/aiac.ijels.v.2n.2p.90

URL: http://dx.doi.org/10.7575/aiac.ijels.v.2n.2p.90

\begin{abstract}
The objective of this study was to assess the role of motivation on teacher performance in Indonesia. This study in an assessment of this aim used deductive approach where a qualitative survey was conducted among students at Universitas Negeri Medan (UNIMED), Indonesia who are assumed to be future teachers. The survey was intended to get their responses on what they feel are the best factors that could motivate them as future teachers among a list of ten motivational factors. In the light of this the study sets to identify the most ranked factors among the ten motivational factors. The analysis from the empirical findings showed that Good Salary was the most ranked factor for both sub groups that made up the sample survey. However, a study from previous researches used in this study showed that different results could be obtained from different groups of already working employees. This study therefore can be seen as an introduction to a more detailed study to be carried by future researchers in the field of teachers' motivation.
\end{abstract}

Keywords: Motivation, Teacher, Performance

\section{Introduction}

\subsection{Background of Study}

When looking at factors that affect job satisfaction, we can find that Agency theory might be helpful as it explains the extent to which organizations need to think of their human resource responsible for producing the output needed by school to meet shareholders' value. Agency theory is concerned with issues related to the ownership of the institution when that ownership is separated from the day-to-day running of the organization.

Agency theory is therefore used to analyze this conflict in interest between the principal (Education and Culture Department of Indonesia) and their headmaster (leaders of these school). Whereby the "headmaster" in keeping with the interest of the shareholders and institutions' goals turn to use financial motivational aspects like bonuses, higher payrolls, pensions, sick allowances, risk payments, and perks to reward and retain their employees and enhance their performance.

There is a strong lobby propounding the view that human resources and their management are the source of competitive advantage for the school, rather than, say, access to capital or use of technology. It is therefore logical to suggest that, attention needs to be paid to the nature of this resource and its management as this will impact on teachers' behavior and performance and consequently the performance of the schools. Indeed, Boxall and Steeneveld (1999) argue that there is no need to prove the relationship between institution's critical influence on performance and labor management, as it is self-evident that the quality of human resource management is a critical influence on the performance of the institution. Concerns for strategic integration, commitment flexibility and quality have called for attention for teachers' motivation and retention. Given this perception, the principal in an organization feels unable to predict teachers' behavior in any given situation and so brings into play various measures to do with incentives in other to tie teachers' needs to those of their institution.

As an approach to mediate the teacher contract, elements of human resource strategy (especially those to do with rewards and retention) can offer a way of ensuring an efficient transaction process that enables both parties to get committed towards the fulfillment of each other's needs. The fundamental problem is to find out what drives or induces people to exploit their potential resources in the way they do in school. Are the issues of motivation and performance positively related? By focusing on the financial aspect of motivation problem like bonus system, allowances perks, salaries, etc as well as by paying attention to the financial aspect of motivation, I intend to probe into the role this aspect on enhancing teachers' performance. I believe, financial motivation has become the most crucial in today's organization, and tying to Mallow's basic needs, non-financial aspect only comes in when financial motivation has failed. Gibson, Ivancevick, Donnelly, (1994:214) a space is then set for non-financial measures. Although in some situations it is being operated side by side, as a research topic for my thesis I will employ the financial aspects of 
motivation used by the principal of school in enhancing their teachers' performance and the extent to which nonfinancial aspects of motivation turn to enhance teachers' performance. To evaluate the methods of performance, motivational factors like satisfies and dissatisfies will be used to evaluate how teacher motivation is enhanced better than financial aspects of motivation.

\subsection{Problem Statements}

As a research question, the research seeks to answer what role motivation plays in enhancing performance in school. This will be possible through analysis of information gathered from students at universitas Negeri Medan, Indonesia. Hence this study is mainly quantitative.

\subsection{Objectives of Study}

In trying to find an answer(s) to the research question and on the basis of the above background discussion and research question, the main purposes developed for this study is to assess the factors that motivate teachers to perform best at teaching. This is done by carrying out a survey in which respondents responding to a survey, ranked the least to most important factor on a list of ten factors and to how these factors influence them.

\section{Literature Review}

Motivation is basically an impulse or desire to make someone do something or to behave as desired for achieving the purpose perfectly. Halepota (2005:16) defines motivation as "a person's active participation and commitment to achieve the prescribed results." Halepota further presents that the concept of motivation is abstract because different strategies produce different results at different times and there is no single strategy that can produce guaranteed favorable results all the times." According to Antomioni (1999:29), "the amount of effort people are willing to put in their work depends on the degree to which they feel their motivational needs will be satisfied. On the other hand, individuals become demotivated if they feel something in the organization prevents them from attaining good outcomes.

A person is motivated if he is doing something, be it his own benefit or for the benefit of others. Admittedly, it is a necessity and important motivation because motivation is needed to excite work diligently to achieve optimal results. Because the wishes and needs of each other are difference, the tools must be different in motivation. This is in accordance with Oman that cited in Newstorm (2007:100) stated that Human beings are reciprocal. If you treat them well, they will treat you well, and if you treat them badly, they will treat you badly. In the Indonesian language, the elaboration of this statement may become that humans do to each other reciprocal, if we treat it well then they will be treated with reverse if bad then they will do bad to us. Therefore, the manager or headmaster of school in Indonesia should provide a suitable motivation for the teacher so that the teacher performance can be improved and the goal of education can be achieved.

In a formal organization, motivation is the duty of a leader to make a subordinate do what must be done. One function of leadership is to motivate the teachers to do their job well. Furthermore, Gibson (1986) says that motivation leads to the first two requirements (needs) associated with a deficiency experienced by a person at a particular time. Deficiencies in this case are physiological, psychological and sociological needs related to the need for social interaction. From here the need is considered as a generator, amplifier and drives people to behave. Second, the importance of the discussion about goals as interpreted by many experts that the real motivation is directed to achieve the goal. Factor purpose or results obtained by a person or a teacher is seen as an attractive power.

The ability of unifying the human aspects into their own difficulties within an organization and a leader must be able to make subordinates in order to have high motivation to work to achieve organizational goals. Leaders can motivate subordinates in various ways (Allen, 1990:249):

a. Inspiring, by inserting themselves into the spirit of the willingness to do so effectively. People inspired by the personality of the leadership, exemplary, and the work he does, consciously or unconsciously.

b. Encouraging, by stimulating people to do what must be done through praise, approval and assistance.

c. Urgent, that makes people feel the need to do what must be done, in some way you need, including coercion, violence, and threats if necessary.

In a bureaucracy good governance needs to be capable of application of motivation models is possible to inspire teachers.

Other than that, the notion of motivation is also expressed by Terry who explains that " Motivation is the desire contained in a person individuals to take action " (cited in Hasibuan , 1989:198). Expression of motivation by Terry is more internal, because the factors driving the emergence of the person who stimulated him to take action. Factors that could push needs, wants, desires that exist in human beings. While Sondra P. Siagian (1979) provides an understanding of motivation as "The entire process of working on a subordinate motive such that they are willing to work with sincerity to achieve the goal" (Siagian, 1979:7). Understanding given is more external Siagian as encouragement that appears in a person that, stimulated by external factors, rather than purely from within. The Malay also conveys the 
same opinion, namely: "the motivation is powering the excitement of working on a stimulant or employees, in order to work with all its resources" (Hasibuan, 1989:184).

In addition, according to Moekijat (1989:190), motivation can be concluded that:

a. Achievement motivation can flourish.

b. People will work faster and better if they sincerely get motivated.

c. The successful people are because truly motivated on achieving their goals.

Based on the theory that has been described above, this indicates a very close relationship between the types of work that is given to the teacher with the opportunity on achieving a sense of satisfaction. Reward also develops the ability of teachers. Measurement of motivation on the part of prospective teachers is to determine their impact on the performance of teachers in Indonesia. Thus, if staff members can work interestingly and challengingly, the teacher will develop their work performance.

\section{Research Method}

The current research is of quantitative type. The numbers of the respondents were 100 candidates of teachers. Using the questionnaire collected the quantitative data.

\section{Data}

This survey was designed to investigate the factors that influence Universitas Negeri Medan students to be motivated at teaching. The respondents were divided into various categories, something that the original Maslow study did not do. As there are differences between what motivates teachers and what teachers want over time. Table 1 below shows the subgroups studied in the survey, the number of respondents and percentage of the subgroup representing the total of 122 respondents.

Table 1. Description of subgroups and the number of respondents

\begin{tabular}{|c|c|c|c|}
\hline Subgroups (Gender) & Number of respondents & $\begin{array}{l}\text { Percentage of } \\
\text { respondents (122) }\end{array}$ & total \\
\hline Males & 43 & $35.25 \%$ & \\
\hline Female & 79 & $64.75 \%$ & \\
\hline
\end{tabular}

It can be observed from the table that the subgroups were fairly represented in the total population of 122 respondents. The respondents surveyed in these study-represented students in different programs of studies at the Universitas Ngegeri Medan, Indonesia. A survey questionnaire administered to respondents asked participants to rank the ten motivational factors according to how each factor would influence them at teaching. The most important factor was to be ranked 5 and the least important factor was to be ranked 1. All factors were to be ranked and no rank could be used more than once. The table below presents the collective rank order of 10 motivational factors according to how important each is in influencing the respondents.

Table 2. Collective rank order of motivating factors according to respondents

\begin{tabular}{lllll}
\hline Rank & Factor & A & B & C \\
\hline $\mathbf{1}$ & Good salary & 540 & 63 & $20.9 \%$ \\
\hline $\mathbf{2}$ & Job satisfaction & 530 & 55 & $18.2 \%$ \\
\hline $\mathbf{3}$ & Promotions & 521 & 20 & $13.6 \%$ \\
\hline $\mathbf{4}$ & Expectation Recognition & 496 & 27 & $13.6 \%$ \\
\hline $\mathbf{5}$ & Organizational/management styles & 466 & 16 & $6.6 \%$ \\
\hline $\mathbf{6}$ & Satisfying goals & 458 & 17 & $8.9 \%$ \\
\hline $\mathbf{7}$ & Team spirit & 455 & 41 & $5.3 \%$ \\
\hline $\mathbf{8}$ & Good working conditions & 445 & 41 & $5.6 \%$ \\
\hline $\mathbf{9}$ & Working hours & 423 & 17 & $5.6 \%$ \\
\hline $\mathbf{1 0}$ & Possibilities of layoffs & 331 & 5 & $1.7 \%$ \\
\hline
\end{tabular}


Notes: Column A. shows the sum of the ranking given to each factor by the total respondents, the smaller the sum of the total rank, the lower the factor was ranked as a motivational factor. Column B. shows the number of times respondents ranked the factors most important

Column C. shows the percentage of respondents who ranked a particular factor as the most important (5)

Sum of respondents who ranked a factor most important $* 100 \%$

Column C $=$

Total number of respondents who ranked any factor most important

Figure 3. The factors that influence respondents' rankings by subgroups

\begin{tabular}{lll}
\hline Factors & Females & Males \\
\hline Good working conditions & 6 & 9 \\
\hline Promotion /expectation & 3 & 3 \\
\hline Organization/management styles & 5 & 7 \\
\hline Team spirit & 9 & 5 \\
\hline Job satisfaction & $\mathbf{2}$ & $\mathbf{2}$ \\
\hline Expectation Recognition & 4 & 4 \\
\hline Working hours & 8 & 8 \\
\hline Goals attainment & 7 & 6 \\
\hline Good salary & 1 & 1 \\
\hline Threats of layoff & 10 & 10 \\
\hline
\end{tabular}

The most obvious general observation that could be made from table 3 above is that the entire group of survey participants and each of the subgroups consistently ranked "job satisfactions the most important motivational factor. Working conditions and threats of layoffs were often than not given the least importance ranking than any of the other factors. The responses or results from the various subgroups are discussed thereof.

\section{Discussion}

It could be seen from the table that column $\mathrm{C}$ is a derivation from column $\mathrm{B}$; this explains why if we count from the excel sheet how many times the number 9 appears on each questionnaire from the total sample size (122) and we get the corresponding result for each factor. Making a summation of this total and dividing the corresponding result above that summation multiplied by $100 \%$ gives us the percentages in column $\mathrm{C}$.

From the review of data, $20.9 \%$ or total of 63 of the 122 participants, as shown in column "B" in table 2. above," ranked Good Salary "as the most important motivational factor. In fact, it was the most popular number one motivational factor across all the categories and subgroups in this survey. The remaining $79.1 \%$ was shared among the 9 other factors while $1.7 \%$ ranked possibilities in layoffs occupying the 10th position as the least important motivational factor. The second highest ranked factor was "Job Satisfaction" representing $18.2 \%$ of the total respondents, followed by promotions $13.6 \%$, Expectation Recognition $13.65 \%$ respectively.

The figures under column " $\mathrm{B}$ " in figure 2 above represent the Excel results. When the total ranking of each factor by each respondent was entered, the total ranking given to "Good Salary" for example was equal to 540 followed by "Job Satisfaction" with a total ranking of 530. The least two factors: working hours and threats of layoff" were both given a total rank of 423 and 331, respectively. Note the lower the total ranking given to a factor, the less important it is as a motivational factor and the lower the total ranking, the lower it is as a motivational factor.

It is interesting to observe that all four factors mostly ranked by Universitas Negeri Medan students fall within the original Maslow study the other motivator factors were ranked 5th, 6th, and 7th respectively in this study. The undisputed ranking of "Good Salary", as the most important factor (63 of the total 122 respondents) clearly shows that Headmaster of School and organizations by no means should underestimate its importance.

Table 3. above shows the categories into which respondents were divided based on the factors that influenced them. The collective rank order of factors by the entire group of surveyed students (122) is presented and the figure also makes it 
possible for the responses of each subgroup to be compared with others and also that of the entire group.

\subsection{Gender (male/female)}

When the responses of men and women were analyzed (table 3. above), no significant differences were found in the ranking of factors or preferences of the two groups. Both men and women (though placing different rankings) ranked four of the same factors among the top five most important motivational factors. However, certain factors which were ranked differently by the two group need a closer look. For example, women ranked Team Spirit and Goals Attainment among the five most important motivational factors, 9th and 7th, while men ranked the same factors outside the top five most important factors. Another difference in ranking of factors between these two groups was also observed between Good working conditions and Organization/management styles. While men ranked these two factors as 9 th and $7^{\text {th }}$, women on the other hand ranked the same factors at 6th and 5th respectively. Considering the results of this survey, one may safely assume that men and women nowadays are interested in making money and climbing the organizational hierarchy since both are same in the four top ranked and also same in the $8^{\text {th }}$ and $10^{\text {th }}$ factors; only factor $5^{\text {th }}, 6^{\text {th }}, 7^{\text {th }}$, and $9^{\text {th }}$ are different.

\section{Conclusion}

The respondents in this survey ranked the following factors as top five factors that motivate them as future teachers : Good Salary, Job Satisfaction, promotions/expectations, Recognition, and organizational/management styles. This study concludes that these factors reflect the current state of affairs in terms of teachers' needs and implies that especially job redesign strategies may be used to reinforce and to motivate teachers today.

The most obvious and major findings emerging from this study is the clear indication of Good Salary as a top motivator among today's future teachers. Strikingly, however is the ranking of a number of lower- order need factors rather than the higher order need factors among the primary and top five most important motivational factors.

In sum, the long-term survival of any organization depends largely on the motivation of its teachers, be it financial or non-financial. Therefore, school/Ministry Education and Culture of Indonesia should be willing to continuously and on regular basis, undertake teachers' surveys such as this one in order to understand what their teachers expect from their current job. The result of such exercises could prove useful for the school, because knowing what their teacher wants and efforts in meeting these needs facilitate a mutual working environment for both the teachers and its management. Finally, I believe the results of this study and those presented and discussed in this study could be useful in helping school or Ministry of Education, and Culture of Indonesia determines what motivates teachers or job-related motivational preferences of their teachers today and in the foreseeable future.

\section{Recommendations}

Additional research should be carried out to gain a continuous view, insight and knowledge of what motivates teachers to perform best on their job. Teacher motivation even after about 50 years of research continues to be one of the problems and challenges facing school today. Furthermore, factors such as technological advances, globalization, retrenchments etc. leave teachers with an uncertain future because most schools today do not guarantee life employment for their teachers as it was the case before. Therefore, there is the need for researchers to continue carrying out teacher surveys so as to determine what motivates teachers to go extra miles. The outcomes of such surveys will help school be at par with changes in teacher's preferences. The outcome of this research shows that Growth rather than Deficient factors are valued more by today's teachers. Therefore, it would be interesting if further research with a much larger sample size could be undertaken to confirm either fully or partly the findings of this study. Further research could also consider other factors such as location of the organization, other demographic factors and regional tendencies (e.g., developed and developing countries).

\section{References}

Allen, Louis A. (1990). Profesi Manajemen. Jakarta: Erlangga

Antomioni, D. (1999). “What motivates middle managers"? Industrial Management, 41 (6) 27-30.

Boxall, P. and Steeneveld, M. (1999). Human resource strategy and competitive advantage: A longitudinal study of engineering consultancies. Journal of Management studies, 36, 443-463.

Gibson, James L. at all. (1986). Organisasi dan Manajemen. Jakarta: Erlangga

Gibson, J.L., Ivancevich, J.M., \& Donnelly, J.H. Jr. (1994). Organizations: Business, Structure, Processes ( $8^{\text {th }}$ Ed.). Boston, MA: Irwin.

Hasibuan, Malayu SP. (1989). Manajemen Dasar, Pengertian dan Masalah. H., Jakarta: Masagung.

Helepota, H.A. (2005) "Motivational Theories and their application in construction". Cost Engineering, 47 (3) 14-35. 
Moekijat (1989). Manajemen Tenaga Kerja dan Hubungan Kerja. Pionir: Bandung.

Newstrom, J W. (2007). Organizational Behavior;Human Behavior at Work. Twelfth Edition. New York: McGraw-Hil.

Siagian, S. P. (1994). Filsafat Administrasi. Jakarta: Gunung Agung.

Siagian, S. P. (1995). Teori Motivasi dan Aplikasinya. Jakarta: Rineke Cipta. 